\title{
Democratic and Educational Background of Information Poverty: The Case of Turkey
}

\author{
Güler Demir \\ Kastamonu University \\ gulerdemir@kastamonu.edu.tr
}

\begin{abstract}
Information poverty is one of the most significant characteristics of developing countries and its causes include multiple complex factors, including educational, scientific and technological contexts, political, social and cultural structures, democratic quality, and humanitarian conditions. The purpose of this study is to examine the situation of information poverty in Turkey, focusing on its democratic and educational aspects. In the scope of the study the basic concept of information poverty is briefly introduced. Then, the particular case of Turkey is presented based on domestic and international literature and other public and official sources. The study concludes Turkey is one of the countries which suffers from information poverty, because of failing to fulfill minimal democratic and educational conditions. Associated problems covered do not seem to be solved in the short term. Recommendations are that the first step in the amelioration of information poverty must be awareness-raising by targeting all governmental and societal segments. A multidimensional approach that addresses all segments and policies of the country may be useful, because there is no single factor that explains the information poverty. Finally, librarians and other intellectual workers have a significant role to play in this process.
\end{abstract}

\section{Introduction}

It is claimed that in the 21 st century, a new social structure called 'information society' has emerged, where information is transformed into an important power. However, it is questionable whether even societies that describe themselves as information and/or developed societies are information societies in a real sense. This article examines whether Turkey meets the democratic and educational requirements needed for an information society. In this context, the important questions to be raised are whether there is a real democratic system ensuring freedom of information access, use and exchange in every aspect of life in Turkey and whether all members of society have enough educational background and qualification to harness the available information access tools and opportunities.

The study concludes that participation in the process of becoming an information society in Turkey has been late. The process has not developed reliably and the existence of information poverty may be due to complex reasons, including especially democratic and educational deficiencies. The necessary steps to address these issues, which require awareness and common willpower, cannot be taken in the short term. Because the complex nature of the elimination of information poverty, primarily requires internalization of values such as democracy and social justice in a real sense, and this necessitates some radical changes. Journal of Contemporary Issues in Education, 2020, 15(1), pp. 65-80. (c) Author(s), Creative Commons Attribution 4.0 (CC BY 4.0) licence. http://ejournals.library.ualberta.ca/index.php/JCIE doi 10.20355/jcie29421 
This theoretical literature-based paper probes 'what questions' have been posed in reliable domestic and international literature to generate a current picture of the situation in Turkey in the study context. The data reported, such as the number of people accessing technological tools like computers, internet, cellphones, etc., and their characteristics is retrieved from the official website of TurkStat (The Turkish Statistical Institute) and analysis (http://www.tuik.gov.tr/Start.do). The basic approach taken in this paper is intended to raise awareness of the situation and promote action research and policy development by librarians alongside others in the interest of the advancement of human rights in Turkey.

\section{The Concept of Information Poverty}

Britz and Lor (2019) point out that

Information has instrumental value because it allows us to make choices, raise our voices, participate in different socio-economic, political, cultural activities and improve our capacity. Access to information should therefore be regarded as an instrumental and basic human right because any vision of the successful implementation and protection of our civil, political, cultural, economic and social rights without the right of access to information pertaining to these rights, would be futile. (p. 17)

In this sense, information poverty is a concept that refers to a persistent lack of access to information as experienced by a group or an individual, usually as a result of many factors, embodied by various types of information-related inequalities (e.g., chronic information illiteracy, lack of broadband internet access, or lack of information resources because of low income or education (Gibson \& Martin, 2019, p. 476).

Information literacy, which is crucial to an information society, requires users to be educated, skilled and not to be excluded from any information channels. Access to information should not be contingent on individuals' social status and income level. Nowadays, as Samek (2007, p. xi) points out, "there are still well informed and misinformed people and a widening gap between rich and poor... The 'knowledge society' has created a new focus of richness as well as of poverty, it has made new divides and differences appear, and it has invented contemporary forms of social exclusion and illiteracy". Additionally, the expansion of human freedoms must be the means and ultimate goal in the construction of the information society. These freedoms will strengthen the individuals' capability to participate in the information society (Daza \& Gigler, 2007, p. 15). So, democratic values ensuring freedom and opportunity for all people without any discrimination should be the basic principle of society.

\section{The Case of Turkey}

Meiklejohn (2004) highlights the role of freedom of speech and democracy in accessing information. Democracy enables people not only access to formal or informal information, but also to use and share it, no matter what its purpose. Education is a very important element Journal of Contemporary Issues in Education, 2020, 15(1), pp. 65-80. (c) Author(s), Creative Commons Attribution 4.0 (CC BY 4.0) licence. http://ejournals.library.ualberta.ca/index.php/JCIE doi 10.20355/jcie29421 
for supporting needed information processes. Y1lmaz (1998, pp. 148, 156) points out that the concepts of information society and information age are used at all levels in many areas, including science, education, policy, and management, etc. However, in Turkey, these deep concepts have become superficial slogans, as a result of not having been sufficiently examined and questioned.

It is believed that the differences in the infrastructure and opportunities of countries in terms of access to information and communication technologies (ICT) led to an increase in the development gap (Y1ldiz \& Akbulut, 2017, p. 3). Technological infrastructure and/or use of ICT alone is not enough to close the gap if there is a lack of consciousness, courage and culture with regard to democratic participation and/or equal opportunities. Democratic internalization and qualified education systems which support pluralism, diversity and freedom are conditional for success.

\section{Participation in Democratic Processes}

In order to illuminate the issue, it is useful to look briefly at the historical background of democracy in Turkey. After the proclamation of the Republic in Turkey (1923), which is the successor state of the Ottoman Empire, Turkey shifted from a single-party to a multi-party regime (1946) and the democratic process was tried in the country. However, in the history of the Republic of Turkey, several coup and coup attempts were made against the government (on 27 May 1960, 12 March 1971, and 12 September 1980). Turkey also experienced a coup attempt on 15 July 2016 (Hali \& Rencuzoğulları, 2017, pp. 259-264). Generally, coups cause serious and permanent impacts and traumas on both individuals and social structure. The effects of social traumas are manifested in the long term (Hobfoll, Galai-Gat, Johnson, \& Watson, 2007). This volatile history has caused many problems, such as human detentions, deaths and injuries, as well as systemic social, economical and psychological damage to the society.

Democracy needs a cultural commitment to be effective in practice. As Kloppenberg (2016, p. 176) argued,

creating democracy is more than a matter of installing the right political plumbing. Constitutions and voting systems may be necessary conditions to democracy, but they alone are insufficient. Political machinery, no matter how carefully crafted, depends upon shared behaviors and habits of mind - what historians and political scientists often call 'political culture'.

In Turkey, a culture of democracy has not taken deep root for many reasons, as Köker (2007) and Mardin (2006) observe. Köker (2007, pp. 228-229) suggests that tutelary democracy in which the ruling groups and the elites are determinant in many areas, such as political, economic, social and cultural, etc., has taken root in Turkey's history. Within this climate, individual and social rights and freedoms are often perceived as threats to the state. This rather patronizing approach, followed by top-down applications, has led to a pattern in which modernist elites decided when the society was ready for democracy. Thus democracy itself Journal of Contemporary Issues in Education, 2020, 15(1), pp. 65-80. 
has not flourished. As Mardin (2006, p. 64) states, the official attitude of the republic was to reject the cosmopolitan structure of Anatolia in which different ethnic, indigenous and religious communities lived together for centuries. They were perceived by the later elite generations as the unnecessary remains of the Ottoman Era.

Keseroğlu (2016, p. 181) observes that "in countries where the culture of democracy has not been completely embraced and where the democratic principle of the separation of executive, judicial, and legislative powers has not been applied, governments may seize the powers of the state". He adds that Turkey is a developing society, and politics are present in its everyday life (p. 194). All individuals in all sectors-from teachers to librarians, civil servants to businessmen-as well as all institutions and organizations, are evaluated politically”.

Information/knowledge is the oxygen of democracy. It gives people the opportunity to examine the actions of the government and to have the right to comment on it. Weak and/or immature governments need secrecy to survive. They can even allow degeneracy on behalf of their interests (Bilgilenme Hakk1 Yasası Madde 19). In the context of the status of freedom of thought in Turkey, there has been a regression, especially in recent years. According to the 2019 World Press Freedom Index of Reporters Without Borders (RSF), Turkey has ranked 157th among 180 countries. The organization reports, "Turkey is the world's biggest jailer of professional journalists" (İstanbul - BIA News Desk, 2019). Most of the court cases of journalists, columnists, and/or writers are judged with the claims of violations of the following articles of the Turkish Penal Code: Defamation (Article 125); Violation of Privacy (Article 134); Provoking commission of offense (Article 214); Praising the offense or the offender (Article 215); Provoking people to be rancorous and hostile (Article 216); Indecency (Article 226); Violation of secrecy (Article 285); Confiscation and destruction of an officially delivered property (Article 288); Insulting Turkishness, the Republic, the organs and institutions of the State (Article 299); Enlistment in foreigner's service (Article 318), and so on. Implementation of these judgements in a manner that limits freedom of media should be terminated (Sözeri, 2015, p. 24).

A constitution is one of the most important determinants of democracy. As Gönenç (2004, p. 108) states, all constitutions of the Republic of Turkey (1924, 1961 and 1982) were created under extraordinary conditions. The Constitution of 1961, the 1971 amendments to the latter, and the Constitution of 1982 bore the stamp of military regimes. So, the 2001 amendments were the most comprehensive ones made by civilians in Turkish constitutional history (Gönenç, 2004, p. 108).

\section{Ulusoy $(2013$, p. 75$)$ states that}

In 2001, the amendment of the Constitution made significant progress by achieving the restriction of the fundamental rights and freedoms system. The restriction of the fundamental rights and freedoms had a layered limitation system before in 2001. But today's freedom and rights can only be restricted by the "related reasons" which are the only reasons specified as regulated within the associated Article. In this aspect 
Article $14^{1}$ of the Constitution was encountered in the form of a general limitation provision in the framework of limitation of the layering order before 2001.

In this context, statements of Petersen and Yanaşmayan, (2020, p. 189) make the issue more controversial. They point out that "although the reformation eased the restrictive approach of the constitution and provided a stronger shield against the abuse of rights and freedom, the article primarily safeguards "the indivisible integrity of the state" and "the democratic and secular order of the Republic based on human rights" against the exercise of rights and freedom". These two are against the challenges of Kurdish nationalism and political Islam. Similarly, the statement of Sağlam (2002, p. 288) points out the partisan characteristic of the amendment. According to Sağlam (p. 288) the 2001 Constitutional Amendments is a some form of reconciliation between parties. In other words, changes were made mostly based on the consensus of the parties. Therefore, there is a lack of holistic approach or a holistic view.

Another issue is related to the phrases 'national security', 'public order' and 'public moral', which are repeated throughout the Constitution of the Republic of Turkey (Türkiye Cumhuriyeti Anayasas1, 1982, 09 November) and which persist. These phrases and generalizations do not only allow for limitations on certain rights, but also can be used subjectively to enforce the provisions. So they are exploitable and abusable.

As pointed out in by Korkmaz (2018, p. 121), in Turkey, press freedom decreased significantly from 2013 onwards and media has begun to suffer from oppressions. The main reasons given for the oppression are actions, such as the 2013 Gezi Park events and the July 15, 2016 coup attempt which caused fear of losing the power of the Government Party (AK Party) rule, which has been in power for 17 years (Korkmaz, 2018, p. 121). Restricting freedom of media on the basis of the 'national security' concept has been a general tendency in Turkey, as is the case in many countries. However, the definition of the concept is not clearly explained in the legislation. Inability to identify the contents of the concepts and expressions used in the laws can lead to dangerous restrictions, which are implemented not only for occasional situations but also more broadly (Sunay, 2001, p. 80).

\section{Literacy and Educational Background}

In the information society, individuals need to possess certain skills, such as questioning, creative thinking and productivity. The role of educational organizations in the information society is changing. Education in the information age aims to encourage creative and innovative people. Today, what is emphasized is that information should not be provided directly to the individual; rather, the individual should be educated on how to reach

\footnotetext{
${ }^{1}$ Art. 14 (as amended on October 3, 2001; Act No. 4709) states: None of the rights and freedoms embodied in the Constitution shall be exercised in the form of activities aiming to violate the indivisible integrity of the State with its territory and nation, and to endanger the existence of the democratic and secular order of the Republic based on human rights. No provision of this Constitution shall be interpreted in a manner that enables the State or individuals to destroy the fundamental rights and freedoms recognized by the Constitution or to stage an activity with the aim of restricting them more extensively than stated in the Constitution. The sanctions to be applied against those who perpetrate activities contrary to these provisions shall be determined by law.
}

Journal of Contemporary Issues in Education, 2020, 15(1), pp. 65-80. 
information effectively. Therefore, an important concept discussed is learning to learn. If the individual knows how to learn, she/he can access the information needed in the most appropriate ways (Çalık \& Sezgin, 2005, p. 63). So, education is one of the most important factors for the information society.

The right to education has been defined in Article 26 of the Universal Declaration of Human Rights. According to the Article 26 (1),

Everyone has the right to education. Education shall be free, at least in the elementary and fundamental stages. Elementary education shall be compulsory. Technical and professional education shall be made generally available and higher education shall be equally accessible to all on the basis of merit. (The United Nations, 1948).

However, in reality, educational equality is restricted due to many factors, including privatization, especially in developing countries (Gutiérrez \& Tanaka, 2009, p. 56). The following explanation sheds some light on the matter:

While schooling is compulsory and enforceable in all high income countries, this is not the case for developing countries, where secondary education is usually not compulsory, and even when it is, enforcement is weak or null, so that attendance levels fall well below $90 \%$. Moreover, in developing economies school attendance has an important opportunity cost for the household, either in terms of household chores or child labor income. Second, private school enrollment in developing countries is usually higher than in high income countries, and while in many high income countries private education is partially financed by public funds, this is rarely the case in low income countries. (Gutiérrez \& Tanaka, 2009, p. 56)

In Turkey, the educational system shifted dramatically after proclamation of the republic. Educational policy was transformed by Western influence during the Ataturk or Republican Era of the 1920s. Before the proclamation of the republic, Turkey was an Islamic Empire ruled by Holy Law. In this era, every aspect of life was directed and regulated by religion, including education. Secular subjects, such as mathematics and science, were not included in the curriculum. They were taught only in reference to religious studies. During the Republican Era, the main goal of Turkey's westernization policy has been to reach the economic and technological level of western countries. "This goal has produced a practical and empirical frame of mind which gives priority to the things which have concrete, practical value in accomplishing this task" (Ünder, 2007, p. 421; see also Stanley, 2013, pp. 7-8).

Çaha (2008, pp. 65-66) points out that Article 42 of the 1982 Turkish Constitution, entitled "Right and Duty of Training and Education", is the basis of many problems in the educational system. This article states "No one shall be deprived of the right to learning and education". Nevertheless, the same article also states "Education shall be conducted along the lines of the principles and reforms of Atatürk, based on contemporary scientific and educational 
principles, under the supervision and control of the State. Educational institutions contravening these principles shall not be established". Çaha (2008) asserts Turkish educational philosophy is based on this understanding in which Atatürk's principles and revolutions are considered as democratic and contemporary values. The problem is that there are different approaches to Atatürk's reforms, both in Turkey and the world. The fact that Atatürk and his reforms symbolize westernization and modernization is true, but there is no consensus about them. Moreover, because of diversity of beliefs, viewpoints, worldviews and political orientations, the tendency of the state to embrace just one approach and impose it on society cannot be considered democratic. Çaha (2008) also puts forward the concept of "contemporary scientific and educational principles", noting there cannot be a clear answer to the question of what contemporary scientific and educational principles are. The contemporary scientific and educational principles were based on positivism in the beginning of the Republic period. Today, positivism is not respected by the academic community or in the modern world because of the growth of many approaches that recognize diversity as an asset (Çaha, 2008). The other is that the concept of "the supervision and control of the State" means that any other system which is out of the determined principles will not be allowed to operate by the state. A democratic state is expected to be objective, not political. In such a monopolistic environment, skills such as creativity and critical thinking are difficult to realize.

According to Alpaydin (2018, p. 25), in Turkey, education policies are not balanced, because they have differed considerably from one government to another. The government expenditure per student is not enough to guarantee equality of opportunity. Moreover, the examination centered model, which has always prevailed over a student-centered model, is negatively impacting students' achievement, causing depression, doubt, and lack of selfconfidence.

A great deal of literature expresses similar criticisms. Gedikoğlu (2005), Y1lmaz (2006), Hareket, Erdoğan and Dündar (2016), Sağlam and Büyükuysal (2013) and Alpaydın (2018) argue that the system is unsuccessful because a parrot-fashion education model is still deeply rooted and needs to be changed to a student-centered learning approach. Foreign language education is not implemented successfuly in secondary schools, high schools and universities (Y1lmaz, 2006). Government and politicians are anxious about foreign languages and Turkey now being at risk of being ineffective in the sciences, culture, arts and commerce (Gedikoğlu, 2005). The budget problems of public institutions and private education cause huge social divisions among students (Y1lmaz, 2006) and the effect of over-crowded classrooms on student and teacher performance (Y1lmaz, 2006; Hareket, Erdoğan and Dündar, 2016) are also big challenges.

Hareket, Erdoğan and Dündar (2016) also identify problems militating against educational achievement. These include approaches that are not open to innovation, support of the status quo, and about the fact that scientific thought has not yet been able to penetrate the system. There is a lack of a democratic climate for students (Sağlam \& Büyükuysal, 2013). The system homogenizes people by ignoring their individualistic characteristics (Hareket, Erdoğan, \& Dündar, 2016). The teachers' lack of empathy, lack of teaching skills and unwillingness to take part in interactive education, and the lack of democratic culture which provides conditions for freedom of speech for students are also negative factors (Duman, Journal of Contemporary Issues in Education, 2020, 15(1), pp. 65-80. 
2008). Sağlam and Büyükuysal (2013) call attention to similar challenges faced by students, noting teachers are not open to alternative ideas and criticisms. Students are prevented from developing creative thinking skills. Gedikoğlu (2005) and Sağlam and Büyükuysal (2013) point out that unnecessary and unplanned changes in the education system make problems more difficult to treat. Gedikoğlu (2005) also mentions that mass migration from rural areas to larger cities causes social adaptation problems. He adds that the feudal structures, which still exist in the East and South-East part of Turkey, cause girls to be left behind. The multiple and diverse aforementioned issues show how information use reflects a complex problematic structure influenced by many factors (e.g., political, economic, social, cultural) in Turkey.

Because literacy rates are basic prerequisites of information use, the situation in Turkey should be considered in this context too. According to the data of TurkStat, the ratio of the illiterates in the age group 15 and above fell to 3.6 percent from 9.2 percent between 2008 and 2018. The percentage of women represented 85 percent of illiterate people (2.197.257 people) in 2018. The proportion of illiterate women in Turkey has decreased to 6.1 percent from 15 percent in the last ten years. In the same period, from 2008 to 2018, the proportion of primary school graduate women aged 25 and over dropped from 44.3 percent to 30.6 percent. Mardin (a city in Southeastern Anatolia) has the lowest literacy rate (91.21 percent) (TurkStat Ulusal Eğitim İstatistikleri Veritaban1, 2019).

In 2018, the rate of 15 years and older college or university graduates in Turkey is about 15.27 percent. The major metropolises constitute the highest proportions. Ankara is the province with the highest rate of graduates of universities or faculties with a rate of 22.41 percent, followed by Istanbul (18.53 percent), İzmir (18.44 percent), Eskişehir (18.16 percent) and Tunceli (17.69 percent). In the same year, the provinces with the lowest rates of college or faculty graduates are Şırnak (9.96 percent), Van (9.25 percent), Muş (8.89 percent), Şanlıurfa (8.34 percent) and Ağrı (8.03 percent), respectively. In Turkey, Southeastern Anatolia Region with the cities of Şırnak and Şanlıurfa, and Eastern Anatolia Region with the cities of Van, Muş and Ağrı, are underdeveloped regions with respect to their socio-economic status compared to the rest of Turkey (TurkStat Ulusal Eğitim İstatistikleri Veritabanı, 2019).

The digital divide is also a major challenge in many world regions, from the United States to the European Union. In the context of digital divide, a small segment of society accesses ICT and joins the world information network, while the majority of the population is effectively excluded. The digital divide has contributed to dichotomous societies, as the information rich and the information poor form a two-tiered system because from education to finding a job, from production to consumption, many communications and transactions with economic and social content are carried out via electronic networks. Although ICT usage in Turkey is increasing every year, factors such as level of education, gender and geographical area are determinants. Those whose educational level is low, who live in undeveloped and rural areas and women do not benefit from ICT-related opportunities. This is indicative of Turkey's significant digital divide problem (Öztürk, 2005, p. 127; Erten, 2019, p. 21). According to the ICT Development Index (2017), Turkey dropped to the 67th spot among 175 countries surveyed in 2017. Compared to the previous year Turkey dropped one step back, falling behind not only developed and developing countries, but also countries such as Saudi Arabia, Uruguay, Hungary, Bulgaria, Poland, Serbia, Kazakhstan, Kuwait, Argentina, Costa Rica, Journal of Contemporary Issues in Education, 2020, 15(1), pp. 65-80. (c) Author(s), Creative Commons Attribution 4.0 (CC BY 4.0) licence. http://ejournals.library.ualberta.ca/index.php/JCIE doi 10.20355/jcie29421 
Azerbaijan, Oman, Romania, Malaysia, Montenegro, Brazil, Bahamas, Macedonia, Lebanon, Trinidad and Tobago, Moldova, and Dominica (TMMOB Elektrik Mühendisleri Odası Bilgi ve İletişim Teknolojileri Komisyonu, 2017, p. 7). A suggested solution is to implement an industrialization model that produces their own high value-added products, based on technology, information and research and development (R \& D), to reduce the costs of access to information technologies. The studies carried out for the poor segments of the society within the scope of social policies should also include issues related to access to information technologies (TMMOB Elektrik Mühendisleri Odası Bilgi ve İletişim Teknolojileri Komisyonu, 2017, p. 84). According to the data gathered and published by Turkstat, the governmental agency responsible for managing and reporting the national statistical data on the demographical, socio economic, cultural development of the country, ICTs tools, such as computers, desktops, laptops, cell phones etc., and internet use has risen considerably in Turkey, in the last 10 to 15 years (TurkStat Hanehalkı Bilişim Teknolojileri Kullanım Araştırması, 2019a). However, as can be seen in the following graphs, the level of education affects the use of computers and the internet. 


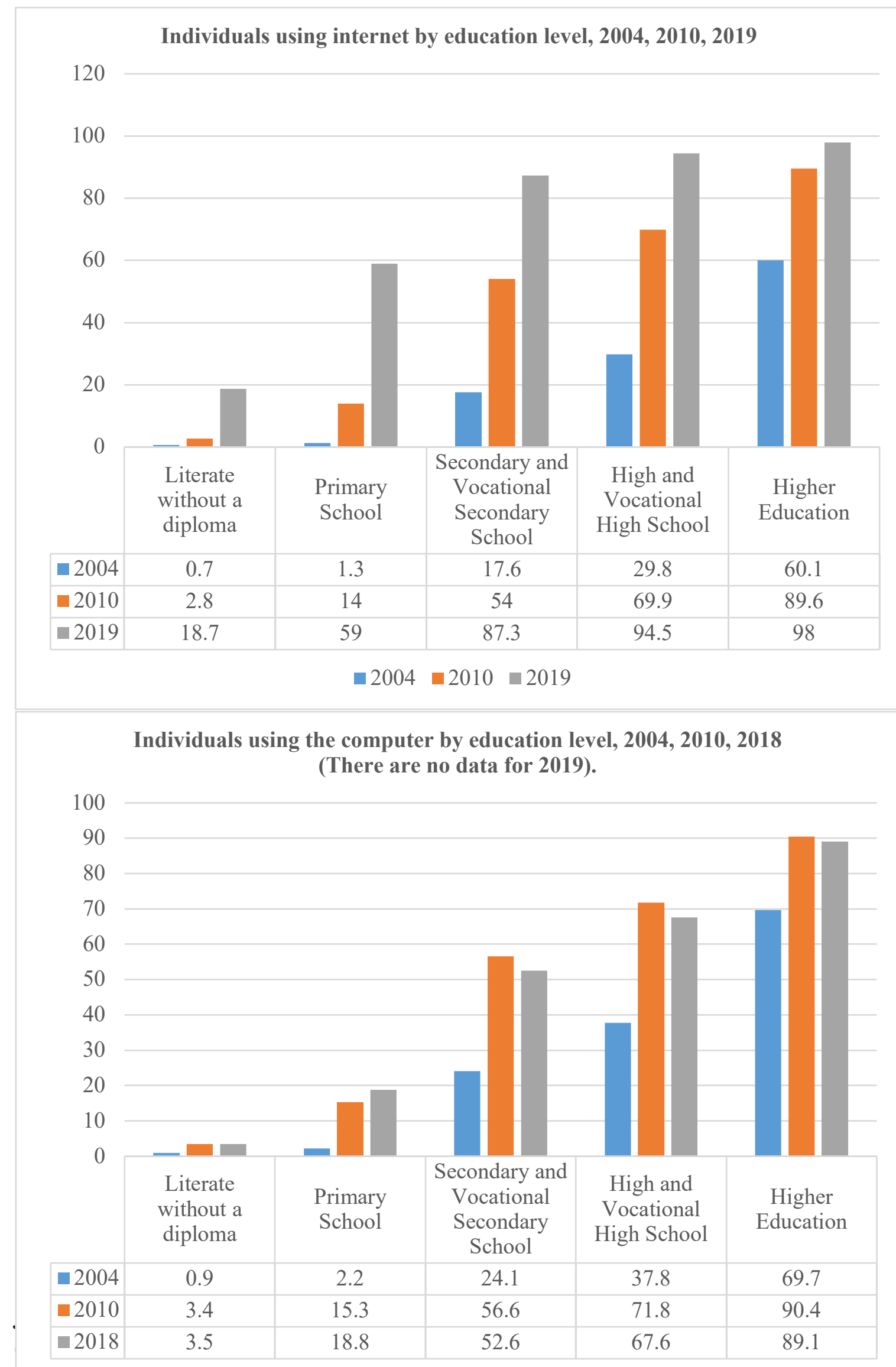


The rate of computer and internet usage of undergraduate and graduates is quite high compared to high school graduates. For individuals who did not graduate from any school and those who graduated from primary school, these rates are very low. The same data based on the conduct of the survey including all persons aged between 16-74 from 2004 through 2019 shows the rate of internet use increased from $72.9 \%$ in 2018 to $75.3 \%$ in 2019 . The rate of Internet use is 81.8 percent for males and 68.9 percent for females in the same age group. Women and men do not have equal access to the internet (TurkStat Hanehalkı Bilişim Teknolojileri Kullanım Araştırması, 2019a).

Additionally, according to the other current statistical data provided by the same source, TurkStat, computer and internet use were found to be highest among students $(83,4 \%$ and 94 , $2 \%$ ), followed by employers ( $80 \%$ and $93,9 \%$ ), regular or casual regular employees $(64,7 \%$ and $92,9 \%)$ and unemployed / jobseekers (58, $2 \%$ and 85, $9 \%)$. Disabled people $(11 \%$ and $21,3 \%)$, retired people (26,2 \% and 51,9\%) and house workers, housewives $(21,8 \%$ and 57 , $9 \%$ ) showed the lowest usage rates. Note: While data showing internet usage, which are given second in the parentheses, are from 2019 estimations, those showing computer usage are from 2018 because there are no data for 2019 (TurkStat Hanehalkı Bilişim Teknolojileri Kullanım Araştırması, 2019a).

Internet use is also a determinant of information society. The TurkStat data provides an insight into the context (TurkStat Hanehalkı Bilişim Teknolojileri Kullanım Araştırması, $2019 \mathrm{~b}$ ). According to the data which shows internet activities of individuals who have accessed the internet in the last 3 months of 2019, the highest reported reasons for internet usage are related to recreational and social purposes; not intellectual and/or learning engagement, significant for information society development. Using instant messaging $(93,9)$, telephone over the internet/video calls (via webcam) $(82,7)$, participating in social networks (creating user profile, posting messages or other contributions) $(81,4)$ and listening to music (e.g. web radio, music streaming) $(71,5)$ are the reasons given for the highest level internet usage. While the rate of reading online news $(69,8)$ is relatively high, the low rate of taking part in on-line consultations or voting to define civic or political issues $(9,1)$ is remarkable. According to the same data, the rate of looking for a job or submitting a job application $(10,6)$ is also low.

The low rate of taking part in on-line consultations or voting to define civic or political issues $(9,1)$ must be taken into consideration as a high probability of being an indicator for measuring the public's self-expression in political affairs. The reasons behind diminished participation or interest in political and community activities is important to consider. A possible explanation is a political environment in which people still hesitate to express their thoughts, especially those that contrast with the dominant thinking or views in Turkey. The other low rate of looking for a job or submitting a job application $(10,6)$ is also remarkable, because it may show a distrust in the opportunities to find a job via the internet, or in any way, especially in a culture in which nepotism and favoritism are common practice and normalized. 


\section{Conclusion and Implications}

Information has always been power and needed in all areas of the life. People have always required information to live their lives, to protect their physical and mental health, to develop freely, improve their educational and/or intellectual skills, find work and pursue a career, to be able to participate in cultural life and society fully, to achieve a good quality of life including spiritual well being. Access to information can make the difference between life and death. Equal access to information is crucial for democratic and egalitarian societies.

However, what is accepted in theory is not always reflected in practice. While, nowadays, when internet and ICT technologies are growing in an uncontrollable way, access to information becomes increasingly complex in regards to its form, its technological advances, the channels where it is distributed, the costs of its functions, the conditions of its accessibility, the skills needed to use it, and so on. All these mentioned (and other) factors can be determinants for benefiting from the opportunities of information sources and services. Internet and related technology use in Turkey has likely grown especially in the last decades. However, the data received from the various sources shows that select parameters, such as educational background, gender (in favor of men) and income negatively impact on the efficiency and efficacy of the use of these tools.

A big factor causing inequality in this context is the level of literacy skills. Because the people who live in undeveloped and rural areas like Eastern Anatolia and Southeastern Anatolia have lower literacy backgrounds and skills than those who live in other parts of Turkey, they can be excluded from benefiting from the use of technological advances. Democracy is a crucial factor for being an information-rich society. In this regard, the situation of Turkey has not painted a promising picture, at least for the last decades. Democracy does not only refer to a political structure, it also requires a cultural internalization of its basic values. In a democratic culture, citizens should have the right to express themselves freely on all matters. Protecting freedom of speech, freedom of producing and sharing any information, including also political matters should be deemed essential. Democracy, which is one of the most determinant factors in this regard, has not been understood completely and appreciated enough in Turkey and education levels have suffered from it.

In political climates, as reflected by the the above-mentioned coups and state of exceptions which allow the state to suspend many rights of the citizens, democratic progresses have been interrupted many times. Turkey has faced many problems as a result, causing instability, economic crisis, poverty, detention of many people, many deaths and injuries and so on. The solutions to these problems are not easy, at least not in the short term. Because no single factor can be considered as the one root of the problems, a multidimensional approach is needed across all sectors, regulations and policies of the country. The first step should be to raise awareness in all levels of the government sector and for the broad society. The provisions restricting the freedom of expression in legislation, such as those in the Constitution should be abolished. The ambiguous articles which can be subjectified and/or exploited should be revised and clarified. Participation of those people engaged in educational institutions, the cultural network and nongovernmental organizations, including teachers, librarians, intellectuals, authors, publishers, can play a key role in mitigating information Journal of Contemporary Issues in Education, 2020, 15(1), pp. 65-80. 
poverty and the digital divide. Samek's (2008, pp. 533-534) point of view about the role of librarians is significant in this context. Librarians can

encourage the conscious use of library and information rhetoric related to human rights (e.g. freedom of expression, freedom of thought, freedom of inquiry, privacy, confidentiality) as a direct entrée to taking a professional interest in broad issues such as sustainable development, pandemics, poverty, war and peace, torture, destruction of cultural resources and government intimidation.

\section{References}

Alpaydın, Y. (2018). Geleceğin Türkiyesinde eğitim. İstanbul: İLKE İlim Kültür Eğitim Derneği.

Bilgilenme Hakk1 Yasas1, Madde 19 (Article 19, The public's right to know: Principles on freedom of information legislation, 1999). Retrieved from www.bilgiedinmehakki.org

Britz, J., \& Lor, P. (2010). The right to be information literate: The core foundation of the knowledge society. Innovation, 41, 8-24. http://dx.doi.org/10.4314/innovation.v41i1.63626

Çaha, Ö. (2008). Eğitim felsefesi ve eğitimde özgürlükler. In Yeni Anayasa'da eğitim ve özgürlükler - Panel Kitabı. (pp. 60-73). Ankara: Eğitim-Bir-Sen Eğitimciler Birliği Sendikası.

Çalık, T., \& Sezgin, F. (2005). Küreselleşme, bilgi toplumu ve eğitim. Kastamonu Eğitim Dergisi, 13(1), 55-66.

Daza, G. B., \& Gigler, B. S. (2007). The concept of information poverty and how to measure it in the Latin American context. In H. Galperin \& J. Mariscal (Eds), Digital poverty: Latin American and Caribbean perspectives (pp. 11-28). Warwickshire, UK: Intermediate Technology Publications Ltd.

Duman, B. (2008). Öğrenme-öğretme sürecindeki entelektüel şizofrenizm. Türk Eğitim Bilimleri Dergisi, 6(2), 287-321. Retrieved from https://dergipark.org.tr/tr/pub/tebd/issue/26112/275110

Erten, P. (2019). Dijital bölünme. Uluslararası Eğitim Bilim ve Teknoloji Dergisi, 5(1), 15 23. Retrieved from https://dergipark.org.tr/tr/pub/uebt/issue/46696/552400

Gedikoğlu, T. (2005). Avrupa birliği sürecinde Türk eğitim sistemi: Sorunlar ve çözüm önerileri. Mersin Üniversitesi Ĕ̌itim Fakültesi Dergisi, 1(1), 66-80. Retrieved from https://dergipark.org.tr/tr/pub/mersinefd/issue/17392/181773

Gibson, A. N., \& Martin, J. D. (2019). Re-situating information poverty: Information marginalization and parents of individuals with disabilities. Journal of the Association for Information Science and Technology, 70(5), 476-487. http://dx.doi.org/10.1002/asi.24128

Gönenç, L. (2004). The 2001 Amendments to the 1982 Constitution of Turkey. Ankara Law Review, l(1), 89-109. http://dx.doi.org/10.1501. Retrieved from http://dergiler.ankara.edu.tr/detail.php?id=64\&sayi_id=1536 
Gutiérrez, C., \& Tanaka, R. (2009). Inequality and education decisions in developing countries. The Journal of Economic Inequality, 7(1), 55-81. http://dx.doi.org/ 10.1007/s10888-008-9095-y

Hali, S., \& Rencuzoğulları, S. (2017). Tarih öğretmen adaylarının, askeri darbelerin siyasi ve sosyal etkisine yönelik görüşlerinin incelenmesi. Turkish Studies, International Periodical for the Languages, Literature and History of Turkish or Turkic, 12(16), 259-276. Retrieved from http://dx.doi.org/10.7827/TurkishStudies. 11922

Hareket, E., Erdoğan, E., \& Dündar, H. (2016). Türk eğitim sistemine ilişkin bir durum çalışması. Ĕ̈itim ve Öğretim Araştırmaları Dergisi, 5(1), 287-299. Retrieved from http://www.jret.org/FileUpload/ks281142/File/31a.erdem_hareket.pdf

Hobfoll, S. E., Galai-Gat, T., Johnson, D. M., \& Watson, P. J. (2007). Terrorism. In F. M. Dattilio and A. Freeman (Eds.), Cognitive-behavioral strategies in crisis intervention. (3rd ed, pp. 428-455). New York, NY: Guilford Press.

ICT Development Index (2017). IDI 2017 Rank. Retrieved from https://www.itu.int/net4/ITUD/idi/2017/index.html

İstanbul - BIA News Desk (2019, 19 April). 2019 WORLD PRESS FREEDOM INDEX BY RSF: Turkey Ranks 157th in Freedom of Press. Retrieved from https://bianet.org/english/freedom-of-expression/207625-turkey-ranks-157th-infreedom-of-press

Keseroğlu, H. S. (2016). Politics and public libraries in the Republic of Turkey. Library Trends, 65(2), 180-197. http://dx.doi.org/10.1353/lib.2016.0030

Korkmaz, G. (2018). Türkiye'de basin özgürlügü̈ (2002-2017) = Press freedom in Turkey (2002-2017). Master Thesis, İstanbul: Beykent Üniversitesi Sosyal Bilimler Enstitüsü Uluslararasi İlișkiler Anabilim Dalı Uluslararasi İlișkiler Bilim Dalı.

Köker, L. (2007). Modernleşme, Kemalizm ve demokrasi. 10. Ed. İstanbul: iletişim Yayıncılık A. Ş.

Mardin, Ş. (2006). Türkiye'de toplum ve siyaset. 13. Ed. İstanbul: İletişim Yayınları. Meiklejohn, A. (2004). Free speech and its relation to self-government. Clark, New Jersey: The Lawbook Exchange.

Öztürk, L. (2005). Türkiye'de dijital eşitsizlik: TÜBİTAK-BİLTEN anketleri üzerine bir değerlendirme, Erciyes Üniversitesi İktisadi ve İdari Bilimler Fakültesi Dergisi, 24, 111-131. Retrieved from https://dergipark.org.tr/tr/pub/erciyesiibd/issue/5881/77819

Perl-Rosenthal, N. (2018). The culture of democracy [Review of the books Toward Democracy: The Struggle for Self-Rule in European and American Thought by James T. Kloppenberg (Nonfiction work) \& A Revolution in Color: The World of John Singleton Copley by Jane Kamensky (Nonfiction work)]. Dissent, 65 (2), pp. 176-180. doi: $10.1353 /$ dss. 2018.0043

Petersen, F. and Yanaşmayan, Z. (Eds.) (2020). The failure of popular constitution making in Turkey: Regressing towards constitutional autocracy. New York: Cambridge University Press.

Sağlam, A. Ç., \& Büyükuysal, E. (2013). Eğitim fakültesi son sınıf öğrencilerinin eleştirel düşünme düzeyleri ve buna yönelik engellere ilişkin görüşleri. International Journal of Human Sciences, 10(1), 258-278. Retrieved from https://www.jhumansciences.com/ojs/index.php/IJHS/article/view/2459 
Sağlam, F . (2002). 2001 yılı Anayasa değişikliğinin yaratabileceği bazı sorunlar ve bunların çözüm olanakları. Anayasa Yargısı , 18 (1) , 288-310. Retrieved from https://dergipark.org.tr/tr/pub/anayasayargisi/issue/52002/678124

Samek, T. (2008). Kütüphane ve bilgi çalışmalarında insan hakları bulguları. Bilgi Dünyası, 9 (2), 527-540. Retrieved from http://www.bd.org.tr/index.php/bd/article/view/333/338

Samek, T. (2007). Librarianship and human rights: A twenty first century guide. Oxford: Chandos Publishing (Oxford) Limited.

Sözeri, C. (2015). Türkiye'de medya-iktidar ilişkileri: Sorunlar ve öneriler. İstanbul: Istanbul Enstitüsü Yayınları. Retrieved from http://platform24.org/Content/Uploads/Editor/T\%C3\%BCrkiye\%E2\%80\%99de\%20M edya- $\% \mathrm{C} 4 \%$ B0ktidar $\% 20 \% \mathrm{C} 4 \% \mathrm{~B} 01 \mathrm{\%} \% \mathrm{C} \%$ 9Fkileri-BASKI.pdf

Stanley, A. (2013). Reforming education in Turkey for the 21st century: A historical guide and recommendations for leaders. (Unpublished master's paper). MAE program. Marquette, Michigan: Northern Michigan University School of Education. Retrieved from https://www.nmu.edu/education/sites/DrupalEducation/files/UserFiles/Stanley_Athena MP.pdf

Sunay, $\bar{R}$. (2001). Avrupa Sözleşmesinde ve Türk Anayasasında ifade hürriyetinin muhtevası ve sinırları, Ankara: Liberal Düşünce Topluluğu Yayınları.

The United Nations (1948). The Universal Declaration of Human Rights._Retrieved from https://www.un.org/en/universal-declaration-human-rights/

TMMOB Elektrik Mühendisleri Odası Bilgi ve İletişim Teknolojileri Komisyonu (2017). Emo bilgi ve iletişim teknolojileri raporu-2016: bilgi ve iletişim teknolojileri yoksulluğu. Ankara: TMMOB Elektrik Mühendisleri Odası. Retrieved from http://www.emo.org.tr/ekler/dbea76742b0af10_ek.pdf

TurkStat Hanehalkı Bilişim Teknolojileri Kullanım Araştırması (2019a). Hanelerde Bilişim Teknolojileri Kullanımı (Türkiye, Kır, Kent), TurkStat. Retrieved from http://www.tuik.gov.tr/PreTablo.do?alt_id=1028

TurkStat Hanehalkı Bilişim Teknolojileri Kullanım Araştırması (2019b). Son Üç Ay Iç̧inde Internet Kullanan Bireylerin Interneti Kişisel Kullanma Amaçları, TurkStat. Retrieved from http://www.tuik.gov.tr/PreTablo.do?alt id=1028

TurkStat Ulusal Eğitim İstatistikleri Veritabanı (2019). Ulusal Eğitim İstatistikleri. Retrieved from https://biruni.tuik.gov.tr/medas/?kn=130\&locale $=$ tr

Ulusoy, D. Ç. (2013). A comparative study of the freedom of expression in Turkey and EU. Ankara University, Faculty of Political Science, The Turkish Yearbook of International Relations, 44, 51-48. Retrieved from http://dergiler.ankara.edu.tr/dergiler/44/1970/20592.pdf

Ünder, H. (2007). Philosophy of education as an academic discipline in Turkey: The past and present. Studies in Philosophy and Education, 27(1), 405-431. Retrieved from http://dx.doi.org/10.1007/s11217-007-9049-z

Yıldız, B. and Akbulut, G. (2017). Dijital bölünme çerçevesinde Türkiye'nin durumunun değerlendirilmesi. The Fifth International Conference in Economics, EconWorld2017@Rome, (pp.1-8). Rome, İtalya. Retrieved from https://wp.econworld.org/wp-content/uploads/2017/03/WP2017005.pdf

Journal of Contemporary Issues in Education, 2020, 15(1), pp. 65-80. 
Yılmaz, B. (1998). Bilgi toplumu: eleştirel bir yaklaşım. Hacettepe Üniversitesi Edebiyat Fakültesi Dergisi, 15(1), 147-158. Retrieved from https://dergipark.org.tr/tr/pub/huefd/issue/41183/503240

Y1lmaz, M. (2006). Türkiye'nin çağdaşlaşma sorunu ve eğitim. U. Ü. Fen-Edebiyat Fakültesi Sosyal Bilimler Dergisi, 7 (10), 1-14. Retrieved from http://static.dergipark.org.tr/article-download/8942/e362/7e00/imp-JA75CE99CB$0 . p d f$ 